\title{
A filterable lytic agent obtained from a red tide bloom that caused lysis of Karenia brevis (Gymnodinum breve) cultures
}

\author{
John H. Paul ${ }^{1, *}$, Lee Houchin ${ }^{1}$, Dale Griffin ${ }^{1}$, Terri Slifko ${ }^{1}$, Mike Guo ${ }^{2}$, \\ Bill Richardson ${ }^{3}$, Karen Steidinger ${ }^{3}$

\footnotetext{
${ }^{1}$ College of Marine Science, University of South Florida, 140 Seventh Ave. S., St. Petersburg, Florida 33701, USA

${ }^{2}$ Center for Advanced Technology, Lakewood High School, 1400 54th Ave. S., St. Petersburg, Florida 33705, USA ${ }^{3}$ Florida Marine Research Institute, 100 Eighth Ave SE, St. Petersburg, Florida 33701, USA
}

\begin{abstract}
A filterable lytic agent (FLA) was obtained from seawater in the southeastern Gulf of Mexico during a red tide bloom that caused lysis of Karenia brevis (formerly Gymnodinium breve) Piney Island. This agent was obtained from $<0.2 \mu \mathrm{m}$ filtrates that were concentrated by ultrafiltration using a $100 \mathrm{kDa}$ filter. The FLA was propagated by passage on $K$. brevis cultures, and the filtered supernatants of such cultures resulted in $K$. brevis lysis when added to such cultures. The lytic activity was lost upon heating to $65^{\circ} \mathrm{C}$ or by $0.02 \mu \mathrm{m}$ filtration. Epifluorescence and transmission electron microscopy (TEM) of supernatants of $K$. brevis cultures treated with the lytic agent indicated a high abundance of viral particles $\left(4 \times 10^{9}\right.$ to $7 \times 10^{9}$ virus-like particles [VLPs] ml $\left.{ }^{-1}\right)$ compared to control cultures $\left(\sim 10^{7} \mathrm{ml}^{-1}\right)$. However, viral particles were seldom found in TEM photomicrograph thin sections of lysing $K$. brevis cells. Although a virus specific for $K$. brevis may have been the FLA, other explanations such as filterable bacteria or bacteriophages specific for bacteria associated with the $K$. brevis cultures cannot be discounted.
\end{abstract}

KEY WORDS: Gymnodinium breve $\cdot$ Karenia brevis $\cdot$ Lytic agent · Viruses

\section{INTRODUCTION}

Karenia brevis (Davis) cf. Hansen \& Moestrup (= Gymnodinium breve) is the causative agent of recurring red tide blooms in the Gulf of Mexico and the southeastern Atlantic USA. Red tide blooms off the coast of Florida caused by $K$. brevis were observed in 21 of $22 \mathrm{yr}$ from 1975 to 1997 (Tester \& Steidinger 1997) and have been reported since the Spanish conquests (Gunther et al. 1948). Toxins produced by K. brevis can result in massive fish kills, and were implicated in the mortality of 700 bottlenosed dolphins off the east coast of the USA in 1987 (Hersh 1989). More recently, K. brevis toxins have been implicated in the mysterious death of 149 Florida manatees in 1995 and 1996 (Landsberg \& Steidinger 1998).

*E-mail: jpaul@seas.marine.usf.edu
Because of the recurring nature and adverse ecological and economic impacts of red tide blooms, methods to control such blooms are under investigation. The approaches taken have been to use physical/chemical methods or biological control methods to facilitate bloom termination. For example, clay flocculation is being investigated as a mechanism of removal of red tide (Karenia brevis) and brown tide (Aureococcus anophagefferens) cells (Sengco et al. 2001). Potential biological control agents include protistan grazers, algicidal bacteria and viruses.

Grazers capable of consuming red tide organisms include mixotrophic dinoflagellates such as Fragilidium mexicanum (Jeong et al. 1999a) as well as protists such as Strombodinopsis (Jeong et al. 1999b). These organisms can usually graze a variety of phytoplankton forms, and not solely one algal type. Thus, competition between more numerous phytoplankton forms 
and Karenia brevis can become an issue in bloom control strategies. Recently, intracellular dinoflagellate parasites such as Ameobophyra sp. have been shown to infect Akashiwo sanguinea (= Gymnodinium sanguineum; Gunderson et al. 1999, Yih \& Coats 2000).

Much attention has been devoted to algicidal bacteria as agents of bloom termination in nature. Algicidal bacteria that kill Karenia brevis, K. mikimotoi (Doucette et al. 1999), Heterosigma akashiwo (Yoshinaga et al. 1998, 1999), Chattonella and Heterocapsa sp. (Kondo et al. 1998, Nagasaki et al. 2000) have been described. Some of these are species specific, while others appear to be group specific (i.e. can kill gymnodinoids; Lovejoy et al. 1998).

Many genera and classes of algae have been shown to be susceptible to viral infection (Safferman \& Morris 1963, Pienaar 1976, Dodds 1979, Milligan \& Cosper 1994, Nagasaki et al. 1994a, Zingone 1995). Sieburth et al. (1988) suggested that the termination of Aureococcus anophagefferens blooms may have been caused by viruses, and subsequently viruses specific for this organism were isolated (Milligan \& Cosper 1994). That red tide organisms such as Heterosigma akashiwo could be lysed by viruses (Nagasaki et al. 1994a,b, 1999, Tai \& Suttle 2001) has suggested that blooms of such organisms may potentially be controlled by viral infection. Other bloom-forming algae shown to be sensitive to viral infection include Phaeocystis (Brussard 2001), Micromonas pusilla (Cottrell \& Suttle 1991), Emiliani huxleyi (Manton \& Leadbeater 1974) and Chysochromulina (Brussard et al. 1996). Viral infection of bloom-forming algae is often strain specific, resulting in the control of clonal variability in such blooms (Suttle 2000, Taratuni et al. 2000).

The termination of toxic dinoflagellate blooms via viral infection has not been reported, largely because of the lack of reports of viruses infective for dinoflagellates. Tartuni et al. (2001) reported the isolation of a virus infective for the novel shellfish-killing dinoflagellate Heterocapsa cirularisquama. In an effort to discover if viruses might cause red tide bloom termination, we have attempted to isolate viruses infective for Karenia brevis by concentrating viral fractions from seawater during red tide blooms. Our work suggests that filterable lytic agents (FLAs) found associated with $K$. brevis blooms can lyse this organism.

\section{MATERIALS AND METHODS}

Cultures. Karenia brevis (Piney Island B4 strain) was grown on $\mathrm{L} 1$ medim at $22.5^{\circ} \mathrm{C}$ and at $50 \mu \mathrm{mol}^{-1} \mathrm{~m}^{-2}$ at the Florida Marine Research Institute in St. Petersburg, Florida, USA.
Field sampling for a brevicidal lytic agent. Surface waters were sampled in a Karenia brevis bloom during a research cruise aboard the RV 'Suncoaster' from December 1 to 5, 1998, and during a bloom off the Mote Marine Laboratory dock in Sarasota on August 24 and September 7, 2001 (Fig. 1). Samples were prefiltered using a $142 \mathrm{~mm} 0.22 \mu \mathrm{m}$ filter (Millipore Durapore GV) under positive pressure (10 to 15 pounds per square inch [psi]; 1998 samples) or remained unfiltered (2001 samples). The microbes in the filtered water were concentrated by vortex flow filtration using a Membrex Rotary Biofiltration device (West Borough, MA) fitted with a $100 \mathrm{kDa}$ filter (Paul et al. 1991, Jiang et al. 1992). In this manner, 20 to $40 \mathrm{l}$ samples were prefiltered and concentrated to a retentate volume of 50 to $60 \mathrm{ml}$.

FLA assay. Twenty-five milliliter aliquots of an actively growing culture of Karenia brevis were carefully placed into $25 \times 150 \mathrm{~mm}$ sterile culture tubes. Culture tubes were cleaned by soaking first in Micro detergent, followed by 5 tap water and 5 deionized (DI) water rinses. The tubes were then soaked in $10 \% \mathrm{HCl}$ followed by 5 DI water rinses and sterilized by autoclaving. For each assay, $1.0 \mathrm{ml}$ of concentrated retentate from a seawater sample (initial assay) or from a prior assay supernatant was added to each of 3 tubes. Cultures were incubated at $50 \mu^{-1} \mathrm{~mol}^{-1} \mathrm{~m}^{-2}$ and $22.5^{\circ} \mathrm{C}$ on a $12 \mathrm{~h}$ light:12 h dark cycle. Control cultures lacked such amendments or were inoculated with $1.0 \mathrm{ml}$ filtered supernatant from a control tube from a prior FLA assay. For most experiments, supernatants from prior FLA experiments were obtained by centrifugation at $15000 \times g$ for $15 \mathrm{~min}$ to remove $K$. brevis cells and

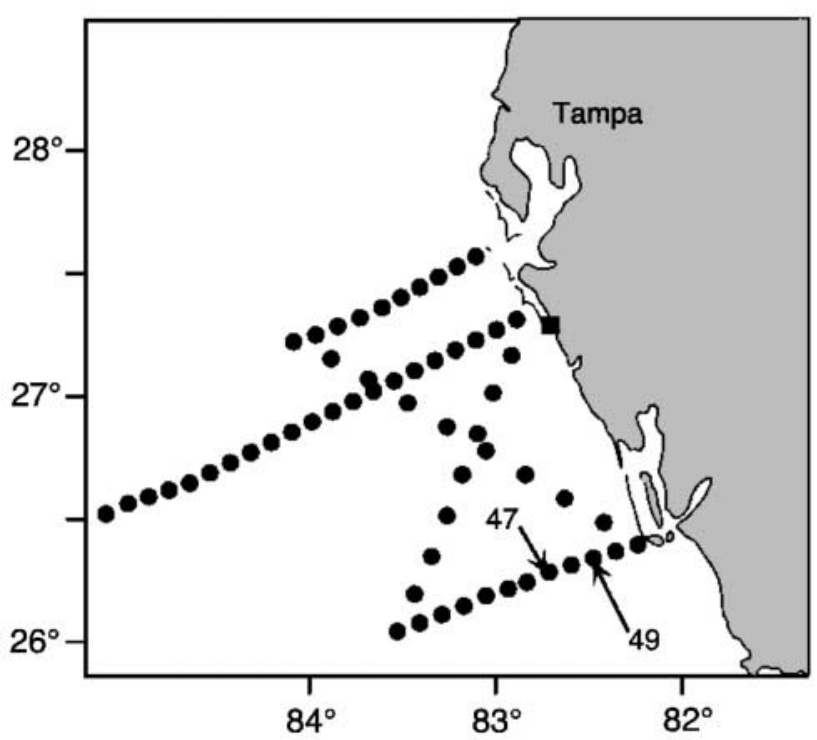

Fig. 1. Cruise track for sampling during red time bloom event in $1998(\bullet)$. Stations that yielded the filterable lytic agent (Stns 47 and 49) are indicated. (घ) Site of sampling for the red tide bloom in 2001 
cell fragments. The supernatants were filtered 3 times through $0.2 \mu \mathrm{m}$ Acrodisc filtration devices (HT Tuffryn, Pall Corporation, Ann Arbor, MI, USA) immediately prior to use. Cell growth was monitored as fluorescence using a 10 absorption unit (AU) fluorometer (Turner Designs, Sunnyvale, CA, USA).

Effect of filtration on FLA activity. To determine the effect of filtration on FLA activity, a filtered supernatant that had previously shown lytic activity was filtered through a $0.02 \mu \mathrm{m}$ Anodisc filter (Whatman) or a $0.2 \mu \mathrm{m}$ Nuclepore filter. One milliliter of such treated culture filtrates was used in the FLA assay described above.

Effect of temperature on FLA activity. To determine the effect of temperature on FLA activity, $0.2 \mu \mathrm{m}$ filtered FLA was heated to 65 or 95 to $100^{\circ} \mathrm{C}$ for $10 \mathrm{~min}$ by immersion in water baths maintained at those temperatures.

Enumeration of virus-like particles (VLPs). In certain experiments, $1 \mathrm{ml}$ samples of each culture tube were taken daily and fixed with $1 \% 0.02 \mu \mathrm{m}$ filtered formalin. Because of the tremendous numbers of viruses produced in certain experiments, it was necessary to dilute these samples 10 - to 1000-fold prior to enumeration. Slides were immediately prepared for viral enumeration by epifluorescence microscopy by the method of Noble \& Fuhrman (1998), except that SYBR Gold (Molecular Probes, Eugene, OR, USA) was used instead of SYBR Green and that staining time was reduced to 12 min. Bacteria were counted simultaneously in certain samples.

Transmission electron microscopic (TEM) analysis. For analysis of the structure of free viral particles, culture supernatants were diluted 1:10 with DI water, and $1 \mu \mathrm{l}$ was spotted on Formvar-coated copper TEM grids (Electron Microscopy Supplies, Ft. Washington, PA). The spot was allowed to air dry and then stained with $2 \%$ uranyl sulfate (Polysciences, Inc, Warrington, PA, USA) for $30 \mathrm{~s}$.

For thin-section analysis of Karenia brevis cells, the methods of Steidinger et al. (1978) were employed.

All TEM samples were examined with a Hitachi 7100 TEM at $75 \mathrm{keV}$.

\section{RESULTS}

Fig. 2A shows the results of incubation of Karenia brevis cells with concentrated viral extracts taken from Stns 47 and 49 of the cruise into the southeastern Gulf of Mexico.
Growth as indicated by culture fluorescence increased over $9 \mathrm{~d}$, and then fluorescence decreased over the next $2 \mathrm{~d}$ (except for the control tubes). To determine if this material (now termed 'filterable lytic agent' or FLA) could be propagated in $K$. brevis cultures, supernatants from each of these treatments were filtered and $1 \mathrm{ml}$ was added to new $K$. brevis cultures (Fig. 2B). The FLA caused a decrease in fluorescence after $8 \mathrm{~d}$ while control cultures continued to grow unaffected.

The FLA was serially passaged similarly 16 times with similar results, except that cell lysis occurred usually after $4 \mathrm{~d}$.

\section{Effect of heat treatment and filtration on FLA activity}

Fig. 3 shows the effect of heat treatment on FLA activity. Heating at 95 or $65^{\circ} \mathrm{C}$ apparently inactivated the FLA. Fig. 4A shows the effect of filtration on FLA activity. Filtration through a $0.02 \mu \mathrm{m}$ filter completely inactivated the FLA activity, whereas filtration through $0.2 \mu \mathrm{m}$ Acrodisc or Nuclepore filter had no effect on FLA activity.
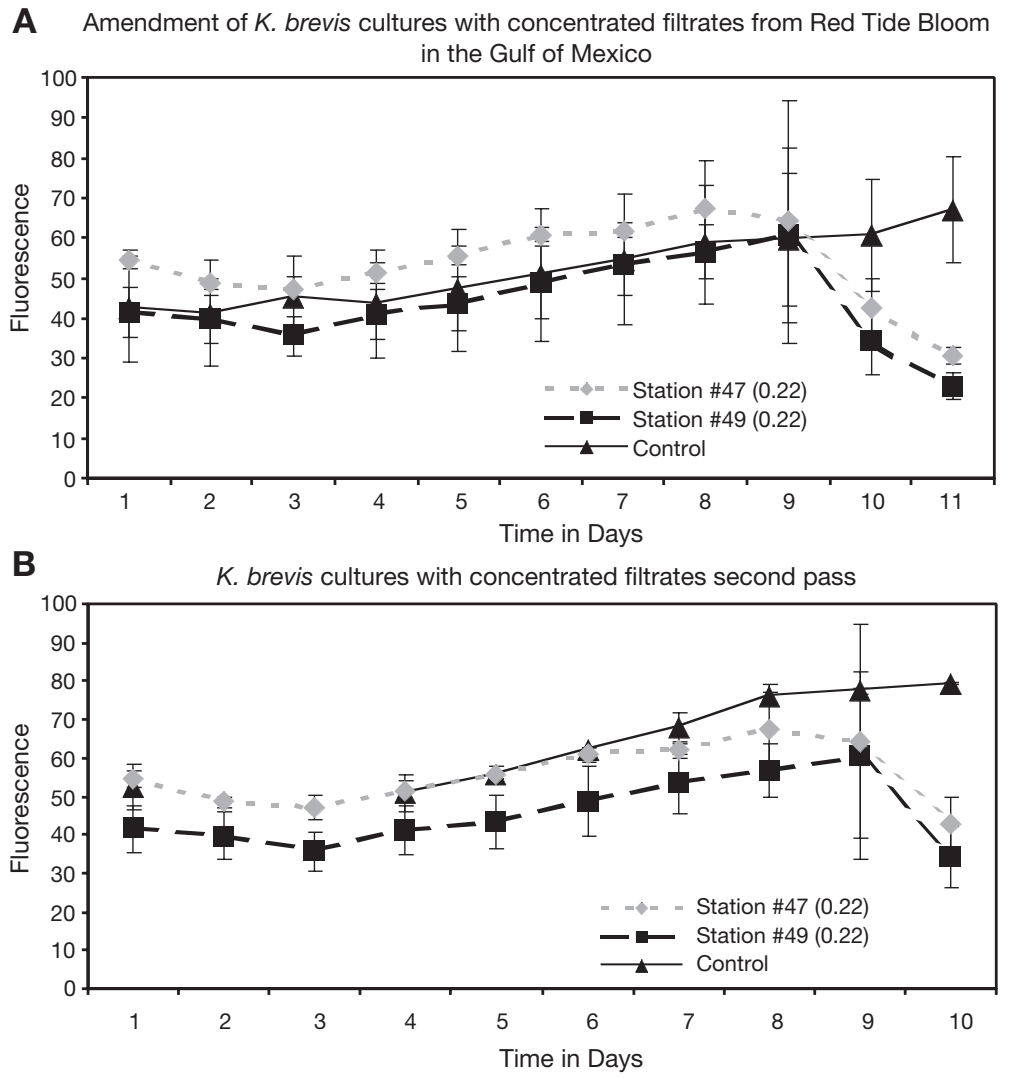

Fig. 2. In vivo fluorescence monitoring of Karenia brevis cultures amended (A) with viral concentrates from Stns 47 and 49 or (B) with filtered supernatants of cultures previously treated with the viral concentrate. Each point is the mean fluorescence of 3 replicate culture tubes $\pm \mathrm{SD}$ 


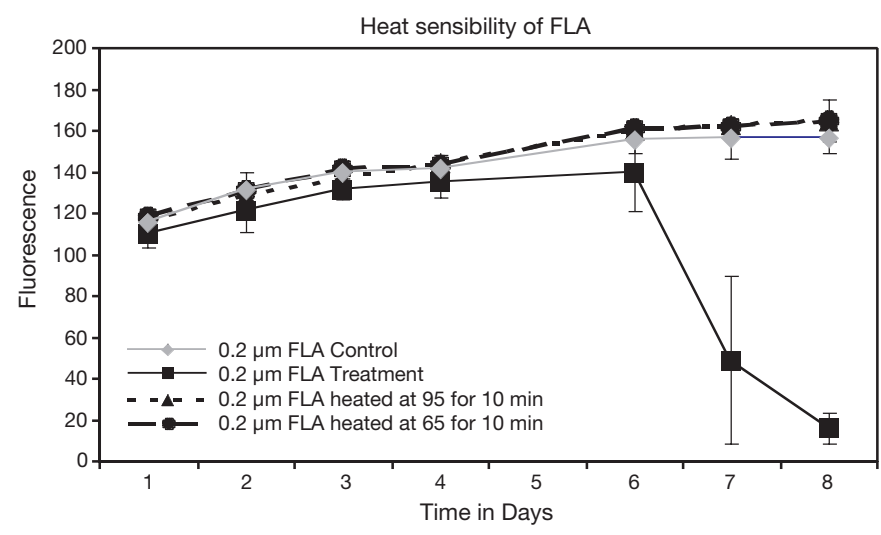

Fig. 3. Heat sensitivity of the filterable lytic agent (FLA) as measured by in vivo culture fluorescence of treated and control Karenia brevis cultures. $K$. brevis cultures were amended with filtrates of control cultures ('0.2 FLA control'), filtrates from cultures that were lysed by the FLA ('0.2 FLA Acrodisc'), the same filtrates but heated for $10 \mathrm{~min}$ at $95^{\circ} \mathrm{C}\left({ }^{\prime} \mathrm{FLA}\right.$ heated at 95 for $10 \mathrm{~min}^{\prime}$ ) or the same filtrates but heated at $65^{\circ} \mathrm{C}$ for $10 \mathrm{~min}$ ('FLA heated at 65 for $10 \mathrm{~min}$ ')

A

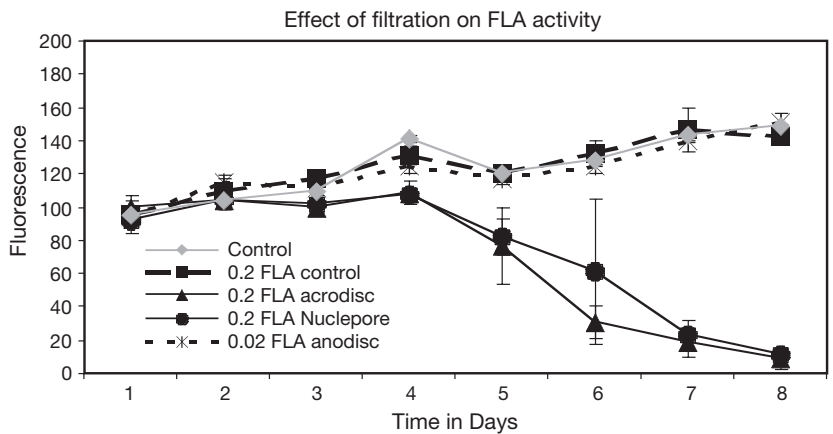

B

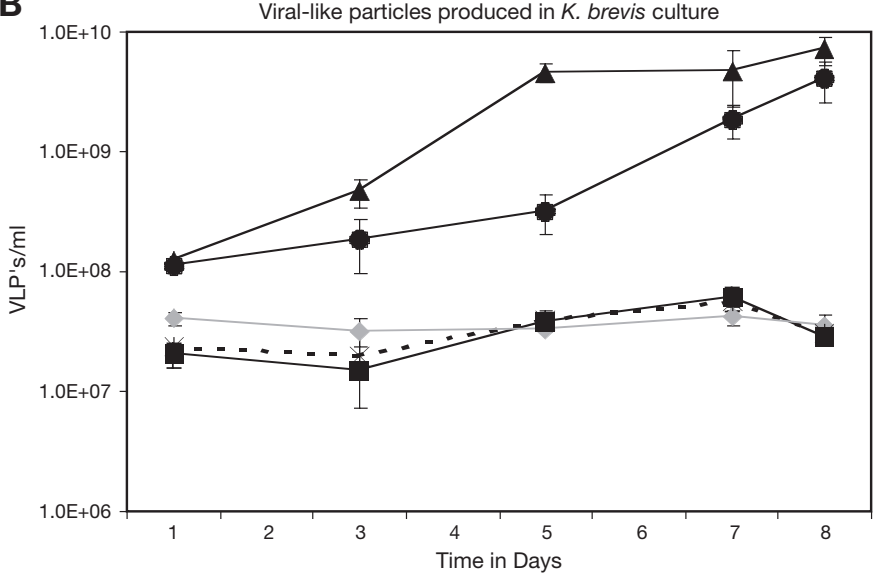

Fig. 4. Effect of filtration treatment of FLA on (A) in vivo culture fluorescence or (B) virus-like particle (VLP) production. Treatments were no addition to the Karenia brevis culture ('Control'), K. brevis cultures amended with filtrates of control cultures ('0.2 FLA control'), cultures amended with $0.2 \mu \mathrm{m}$ filtered supernatants of cultures that were lysed by the FLA ('0.2 FLA Acrodisc' or '0.2 FLA Nuclepore') and cultures amended with $0.02 \mu \mathrm{m}$ filtered supernatant ('0.02 FLA Anodisc'). Each point is the mean of 3 fluorescence readings (Panel A) or 9 slides (3 per tube) $\pm 1 \mathrm{SD}$

\section{Enumeration of VLPs in cultures}

Fig. 4B shows enumeration of VLPs in experiments using the FLA. Cultures inoculated with the FLA had nearly twice the levels of VLPs at the initiation of the experiment and nearly 2 orders of magnitude more than controls at the conclusion of the experiment $(4 \times$ $10^{9}$ to $7 \times 10^{9}$ vs $3 \times 10^{7}$ to $4 \times 10^{7}$ ).

\section{TEM analysis of FLA}

Fig. 5 shows TEM analysis of uranyl sulfate-stained preparations of FLA samples. A dominant siphoviridae was observed in FLA preparations (Fig. 5A,B). This phage had a distinct morphology, with a 'stack of coins'-like tail, and a head $37.3 \pm 2.3 \mathrm{~nm}$ in diameter and a tail $249 \pm 2.0 \mathrm{~nm}$ in length. Other VLPs were also present (Fig. 5C,D), but these were encountered less frequently than the stacked-coin siphoviridae.

\section{TEM analysis of Karenia brevis cells treated with the FLA}

Fig. 6 is a composite TEM photomicrograph of thinsectioned preparations of Karenia brevis cells. Fig. 6A shows a healthy, uninfected $K$. brevis cell while Fig. 6B to D show cells treated with the FLA. It was difficult to locate cells in such preparations that still maintained a recognizable cell wall. Typically such cells were highly vacuolated (Fig. 6B) and had many bacteria-like bodies associated with them. No cells were observed to contain numerous viral particles although an occasional virus particle was observed (Fig. 6D).
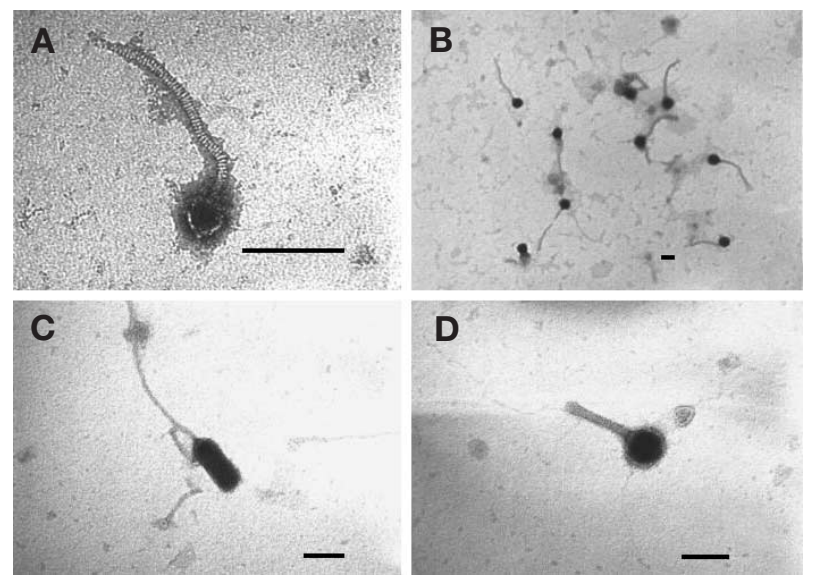

Fig. 5. Transmission electron photomicrographs of viruses found in supernatants of Karenia brevis cultures treated with FLA. $(\mathrm{A}, \mathrm{B})$ Dominant siphoviridae found in FLA-treated cultures with 'stack of coins' tail morphology. $(\mathrm{C}, \mathrm{D})$ Examples of other viruses occasionally encountered in FLA-treated $K$. brevis cultures. Scale bars $=100 \mathrm{~nm}$ 


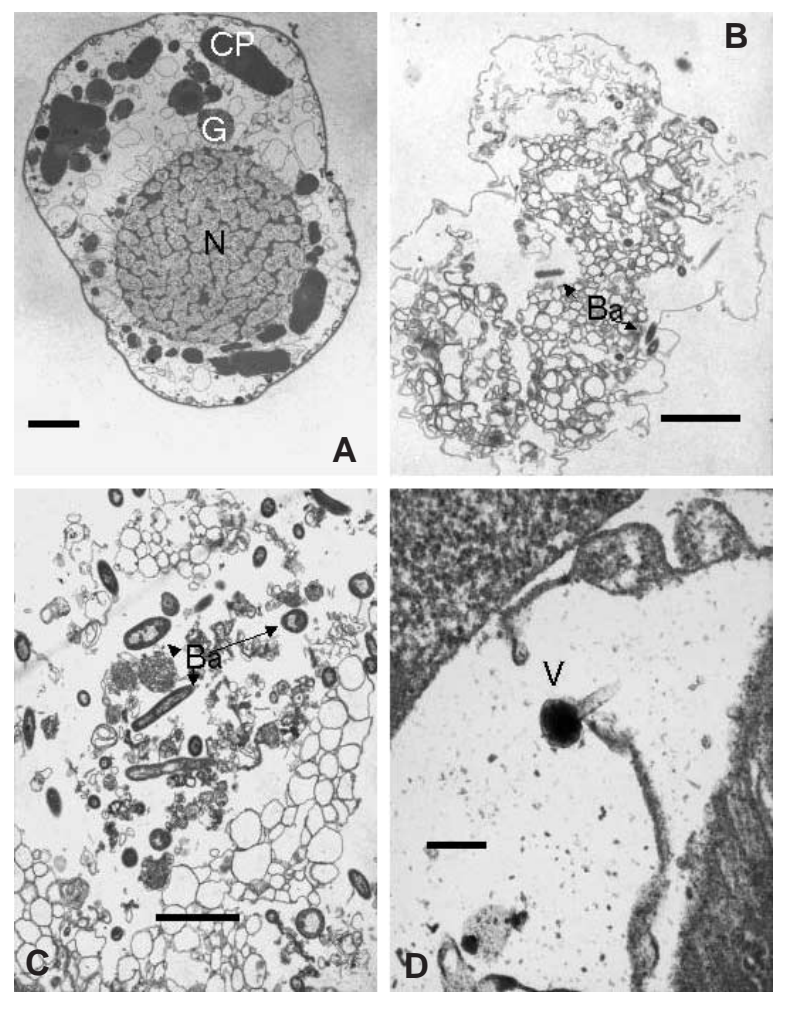

Fig. 6. Transmission electron photomicrographs of thin sections of Karenia brevis cells from (A) control and $(\mathrm{C}, \mathrm{D})$ FLA-treated cultures. Ba: bacteria; CP: chloroplast; G: golgi body; N: nucleus; V: virus-like particle. Scale bars $=2 \mu \mathrm{m}$, except for (D), where it is $200 \mathrm{~nm}$

\section{Loss of lytic activity}

In December 1999, 1 yr after the original 'isolation' of the FLA, the agent (or culture extracts) lost activity toward Karenia brevis after many serial passages in $K$. brevis cultures. Further attempts to 'revive' the lytic agent by passage on fresh $K$. brevis cultures were unsuccessful.

\section{Filterable lytic activity associated with a bloom off Sarasota}

Fig. 7A shows the effect of a FLA collected from a bloom off Sarasota, Florida, on Karenia brevis in vivo fluorescence. The results shown are for the direct use of a filtered retentate collected on September 7, 2001, and the second passage of a retentate collected on August 24, 2001. This lytic agent lost activity after 3 passages. Fig. 7B shows the viral and bacterial direct counts measured at the termination of the experiment in the control cultures and those treated with the FLA. Both viral and bacterial counts were elevated in cultures treated with the FLA compared to controls.
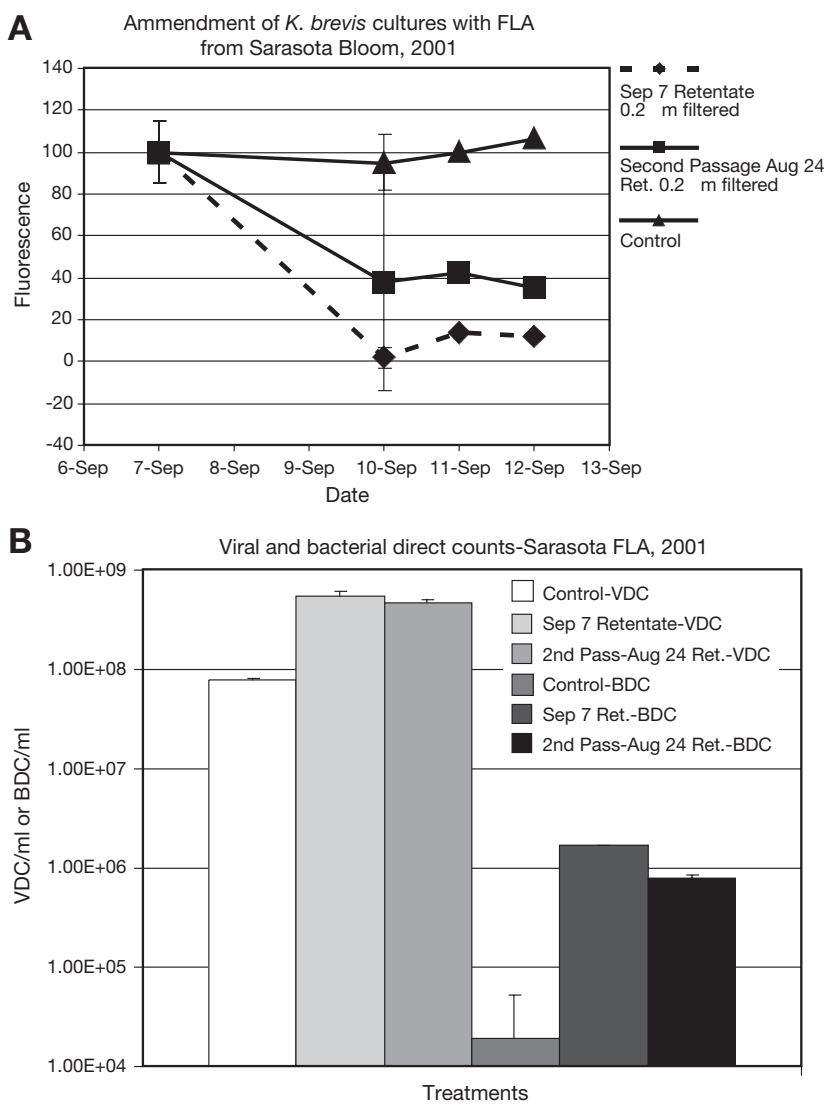

Fig. 7. Filterable lytic agent from Sarasota, Florida, USA in 2001. (A) Effect of FLA on in vivo fluorescence of Karenia brevis cultures, from the September 7, 2001, sampling event (dashed line with diamonds) or the second passage of the FLA from the August 24, 2001, sampling (squares). (B) Bacterial (BDC) and viral direct counts (VDC) taken from the last sampling of the experiment plotted in (A)

\section{DISCUSSION}

We have described a FLA obtained from the Gulf of Mexico that resulted in lysis of cell populations of the Piney Island strain B4 of Karenia brevis. The FLA was heat sensitive and could be removed by $0.02 \mu \mathrm{m}$ filtration. This material was passaged in $K$. brevis cultures for nearly a year before lytic activity was lost. The observations of high viral titers in the filtrates of samples after cell lysis suggested the involvement of a virus in this process, and a numerically dominant siphoviridae was observed by TEM in treated culture supernatants. However, no (or very few) viruses were observed in TEM photomicrographs of lysing cells. Instead, bacteria were observed in thin sections of lysing cells. Additionally, the onset of lysis (originally 7 to $9 \mathrm{~d}$ after addition of FLA but then $5 \mathrm{~d}$ after serial passages) was not consistent with other algal viral infections, which typically take 24 to $48 \mathrm{~h}$ to effect lysis 
(Cottrel \& Suttle 1994, Nagasaki et al. 1994a). A similar observation of a FLA that was active against Gymnodinium mikimotoi, Tetraselmis sp. and Alexandrium catenella was found in seawater from Funka Bay, Hokkaido, Japan (Onji et al. 1999, 2000). This 'viruslike suppressive agent' was also sensitive to heat treatment $\left(50^{\circ} \mathrm{C}\right.$ for $\left.30 \mathrm{~min}\right)$ and $0.05 \mu \mathrm{m}$ filtration, as well as RNase treatment, exposure to $\mathrm{pH}$ 5.0, UV treatment and protease digestion. As in our study, TEM observation showed severely damaged cells after FLA treatment but no indication of viruses (or bacteria) in bursting cells.

We hypothesize that the lysis observed was not the direct effect of a virus on Karenia brevis but rather the result of a viral-bacterial interaction. It is possible that a bacterium performing a positive effector role on $K$. brevis (providing an organic nutrient, cofactor, etc.) was present in the culture and that the virus removed or lowered the concentration of this bacterium. Also, treatment of cultures with such a virus may have selected for a phage-resistant bacterium, which might explain the loss of lytic activity. Alternatively, it may be that the virus caused lysis of a 'neutral' bacterium in the culture that, when lysed, released a lytic agent, enzyme or other algicidal material. It may be that storage of such virus at $4^{\circ} \mathrm{C}$ resulted in inactivation, as was shown for Heterosigma akashiwo virus $(\mathrm{HaV})$; storage of $\mathrm{HaV}$ at $5^{\circ} \mathrm{C}$ in the dark resulted in its rapid inactivation (Nagasaki \& Yamaguchi 1998). We feel that the bacterial component of the $K$. brevis cultures used may have undergone a change, such that it was no longer sensitive to the virus in the FLA. Using a bacterial host obtained from the $K$. brevis culture, we isolated a virus that was morphologically similar to the distinctive siphoviridae observed after $K$. brevis lysis. However, preliminary studies suggested that this virus did not result in $K$. brevis lysis. However, $K$. brevis cultures at that time were no longer sensitive to the FLA.

Karenia brevis has not yet been cultivated axenically for any period of time. Our studies show that such cultures are mixtures of $K$. brevis cells, a diverse bacterial community, along with their phages. Preliminary evidence suggests that some of the bacteria in these cultures are lysogens (Paul et al. 2000). Prophage induction may be occurring during the lytic events observed, further complicating the interpretation of our results.

Suttle (2000) noted that a previous report of a particular virus causing the diatom Navicula sp. to lyse (Suttle et al. 1990, 1991) was really a bacterium that copurified with the virus (Chan et al. 1997). Suttle (2000) concludes that 'to conclusively demonstrate that a lytic agent is viral, it must be propagated on an axenic host.' If that is not possible, morphologically similar viral particles should be shown to occur in infected cells (Suttle 2000). Neither of these criteria were met in this study. We triple filtered our FLA and tested sterility by observing growth (or the lack of) in nutrient media. This does not preclude the possibility that a small bacterium (or viroid) may have been the lytic agent.

A second FLA was obtained from a Karenia brevis bloom in Sarasota nearly 3 yr after we obtained the first FLA. This agent behaved similarly to the original agent, yet seemed to lack the virulence, in that it could be passaged only 3 times before it lost lytic activity. Viral direct counts in cultures treated with the lytic agent were lower $\left(4.6 \times 10^{8}\right.$ to $\left.5.5 \times 10^{8} \mathrm{ml}^{-1}\right)$ than those of the 1998 lytic agent $\left(4 \times 10^{9}\right.$ to $\left.7 \times 10^{9} \mathrm{ml}^{-1}\right)$.

Our results show that FLAs can occur in water supporting red tide blooms and that these agents may cause rapid bloom collapse. We are currently examining other blooms for the presence of FLAs.

Acknowledgements. This work was supported by a NOAA/ ECOHAB grant to J.H.P.

\section{LITERATURE CITED}

Brussard CP (2001) Do viruses affect the population dynamics of bloom forming Phaeocyctis species under nutrient stress? Proceedings of the American Society of Limnology and Oceanography 2001 Aquatic Sciences Meeting, Albequerque, NM

Brussard CPD, Kempers RS, Kop AJ, Riegman R, Heldal M (1996) Virus-like particles in a summer bloom of Emiliani huxleyi in the North Sea. Aquat Microb Ecol 10:105-113

Chan AM, Kacsmarska I, Suttle CA (1997) Isolation and characterization of a species-specific bacterial pathogen which lyses the marine diatom Navicula pulchripora. Abstracts of the American Society of Limnology and Oceangraphy, Santa Fe, NM, p 121

Cottrell MT, Suttle CA (1991) Widespread occurrence and clonal variation in viruses which cause lysis of a cosmopolitan, eukaryotic marine phytoplanktoer, Micromonas pusilla. Mar Ecol Prog Ser 78:1-9

Cottrell MT, Suttle CA (1994) Dynamics of a lytic virus infecting the photosynthetic marine picoflagellate, Micromonas pusilla (Prasinophyceae). Limnol Oceanogr 40:730-739

Dodds JA (1979) Viruses of marine algae. Experientia 35: $440-442$

Doucette GJ, McGovern ER, Babinchak JA (1999) Algicidal bacteria active against Karenia brevis (Dinophyceae). I. Bacterial isolation and characterization of killing activity. J Phycol 35:1447-1454

Gunderson JH, Goss SH, Coats DW (1999) The phylogenetic position of Amoebophyra sp. infecting Gymnodinium sanguineum. J Eukaryot Microbiol 46:194-197

Gunther G, Williams RH, Davis CC, Smith FGW (1948) Catastrophic mass mortality of marine animals and coincident phytoplankton bloom on the west coast of Florida, November 1946 to August 1947. Ecol Monogr 18:311-324

Hersh SH (1989) Why the dolphins die. Sea Front Jul-Aug: 246-248

Jeong HJ, Shim HH, Kim JS, Park JY, Lee CW, Lee Y (1999a) Feeding by the mixotrophic thecate dinoflagellate Fragilidium cf. mexicanum on red-tide and toxic dinoflagellates. Mar Ecol Prog Ser 176:263-277 
Jeong HJ, Shim HH, Lee CW, Kim JS, Koh SM (1999b) Growth and grazing rates of the marine panktonic ciliate Strombidinopsis sp. on red-tide and toxic dinoflagellates. J Eukaryot Microbiol 46:69-76

Jiang SC, Thurmond JM, Pichard SL, Paul JH (1992) Concentration of microbial populations from aquatic environments by vortex flow filtration. Mar Ecol Prog Ser 80: 101-107

Kondo R, Imai I, Fukami K, Minami A, Hiroidhi S (1999) Phylogenetic analysis of algicidal bacteria (family Flavobacteriaceae) and selective detection by PCR using a specific primer set. Fish Sci 65:432-435

Landsberg JH, Steidinger KA (1998) A historical review of Gymnodinium breve red tides implicated in mass mortalities of the manatee (Trichechus mantus latirostris) in Florida, USA. Harmful Algal Bloom, Proceedings International Conference, Vigo

Lovejoy C, Bowman JP, Hallegraeff GM (1998) Algicidal effects of a novel marine Pseudoalteromonas isolate (class Proteobacteria, gamma subdivision) on harmful algal bloom species of the genera Chattonella, Gymnodinium and Heterosigma. Appl Environ Microbiol 64:2806-2813

Manton I, Leadbeater BSC (1974) Fine-structural observations on six species of Chrysochromulina from wild Danis marine nanoplankton, including a description of C. Campanulifera sp. nov. and a preliminary summary of the nanoplankton as a whole. Kongel Dan Vidensk Selsk Biol Skr 20:1-26

Milligan KLD, Cosper EM (1994) Isolation of virus capable of lysing the brown tide microalga, Aureococcus anophagefferens. Science 266:805-807

Nagasaki K, Yamaguchi M (1998) Effect of temperature on the algicidal activity and the stability of HaV (Heterosigma akashiwo virus). Aquat Microb Ecol 15:211-216

Nagasaki K, Ando M, Itakura S, Imai I, Ishida Y (1994a) Viral mortality in the final stage of Heterosigma akashiwo red tide. J Plankton Res 16:1595-1599

Nagasaki K, Ando M, Imai I, Itakura S, Ishida Y (1994b) Viruslike particles in Heterosigma akashiwo (Raphidophyceae): a possible red tide disintegration mechanism. Mar Biol 119:307-312

Nagasaki K, Tarutani K, Yamaguchi M (1999) Cluster analysis on algicidal activity of $\mathrm{HaV}$ clones and virus sensitivity of Heterosigma akashiwo (Raphidophyceae). J Plankton Res 21:2219-2226

Nagasaki K, Yamaguchi M, Imai I (2000) Algicidal activity of a killer bacterium against the harmful red tide dinoflagellate Heterocapsa circularisquama isolated from Ago Bay, Japan. Nippon Suisan Gakkaishi 66:666-673

Noble RT, Fuhrman JA (1998) SYBR Green I counts of viruses and bacteria. Aquat Microb Ecol 14:113-118

Onji M, Sawabe T, Ezura Y (1999) Growth suppression of the marine phytoplankton Alexandrium catanella and Tetraselmis sp caused by ultrfiltrated seawater collected from coastal area on the mouth of Funka Bay. Fish Sci 65: 687-693

Onji M, Sawabe T, Ezura Y (2000) Characteristic of virus like growth suppression agents against phytoplankton obtained from seawater at the mouth of Funka Bay, Hokkaido, Japan. Fish Sci 66:38-43

Paul JH, Jiang SC, Thurmond JM, Rose JB (1991) Concentration of viruses and dissolved DNA from aquatic environments by vortex flow filtration. Appl Environ Microbiol $57: 2197-2204$

Editorial responsibility: David Caron,

Los Angeles, California, USA
Paul JH, Houchin L, Griffin D, Slifko T, Guo M (2000) Searching for viruses infective for Gymnodinium breve. Symposium on Harmful Marine Algae in the US, Woods Hole, MA, p 155

Pienaar RN (1976) Virus-like particles in three species of phytoplankton from San Juan Island, Washington. Phycologia 15:185-190

Safferman RS, Morris ME (1963) Algal virus: isolation. Science 140:679-680

Sengco MR, Li AS, Tugend K, Kulis D, Anderson DM (2001) Removal of red- and brown-tide cells using clay flocculation. I. Laboratory culture experiments with Gymnodinium breve. Mar Ecol Prog Ser 210:41-53

Sieburth JM, Johnson PW, Hargraves PE (1988) Ultrastructure and ecology of Aureococcus anophagofferens Gen. Set. Sp. Nov. (Chrysophyceae): the dominant picoplankton during a bloom in Narragansett Bay, Rhode Island, Summer 1985. J Phycol 24:416-425

Steidinger KA, Truby EW, Dawes CJ (1978) Ultrastructure of the red tide dinoflagellate Gymnodinium breve. I. General description. J Phycol 14:72-79

Suttle CA (2000) Ecological, evolutionary, and geochemical consequences of viral infection of cyanobacteria and eukaryotic algae. In: Hurst CJ (ed) Viral ecology. Academic Press, San Diego, p 247-296

Suttle CA, Chan AM, Cottrell MT (1990) Infection of phytoplankton by viruses and reduction of primary productivity. Nature 347:467-469

Suttle CA, Chan AM, Cottrell MT (1991) Use of ultrafiltration to isolate viruses from seawater which are pathogens of marine phytoplankton. Appl Environ Microbiol 57:721-726

Tai V, Suttle CA (2001) Two novel viruses causing lysis of the toxic bloom-forming alga Heterosigma akashiwo (Raphidophyceae). Abstracts of the American Society of Limnology and Oceanography 2001 Aquatic Sciences Meeting, Albequerque, NM, p 137

Taratuni K, Nagasaki K, Yamaguchi M (2000) Viral impacts on total abundance and clonal composition of harmful bloom-forming phytoplankton Heterosigma akashiwo. Appl Environ Microbiol 66:4916

Taratuni K, Nagasaki K, Itakura S, Yamaguchi M (2001) Isolation of a virus infecting the novel shellfish-killing dinoflagellate Heterocapsa circularisquama. Aquat Microb Ecol 23:102-111

Tester PA, Steidinger KA (1997) Gymnodinium breve red tide blooms: initiation, transport, and consequences of surface circulation. Limnol Oceanogr 45:1039-1051

Yih W, Coats DW (2000) Infection f Gymnodinium sanguineum by the dinoflagellate Amoebophyra sp.: effect of nutrient environment on parasite generation time, reproduction, and infectivity. J Eukaryot Microbiol 47:504-510

Yoshinaga I, Kim MC, Katanozaka N, Imai I, Uchida A, Ishida Y (1998) Population structure of algicidal marine bacteria targeting the red tide forming alga Heterosigma akashiwo (Raphidophyceae) determined by restriction fragment length polymorphism analysis of the bacterial $16 \mathrm{~S}$ ribosomal RNA genes. Mar Ecol Prog Ser 170:33-44

Yoshinaga I, Kim MC, Tsujino K, Nakajima M, Yamamoto K, Uchida A, Ishida Y (1999) Ribotype analysis of KAKB (Heterosigma akashiwo-killing bacteria) strins isolated during termination period of a $H$. akashiwo bloom occurred in Osaka Bay. Fish Sci 65:768-787

Zingone A (1995) The role of viruses in the dynamics of phytoplankton blooms. G Bot Ital 129:415-423

Submitted: July 16, 2001; Accepted: November 26, 2001

Proofs received from author(s): January 14, 2002 